Rafał Michalski

Uniwersytet Mikołaja Kopernika, Toruń

e-mail: metabasis1@wp.pl

\title{
Melancholia i katastrofa w barokowym dramacie żałobnym
}

DOI: http://dx.doi.org/10.12775/RF.2018.013

\section{Wstęp}

Niedoszła rozprawa habilitacyjna Waltera Benjamina Źródło dramatu żałobnego w Niemczech ${ }^{1}$ przez długi czas ignorowana, poza nielicznymi wyjątkami, w środowisku akademickim doczekała się pod koniec XX i początku XXI na całym świecie niezwykle intensywnej recepcji, która sama $\mathrm{w}$ sobie zasługiwałaby na oddzielne opracowanie. Rozprawa zawiera wiele wątków szczegółowych i opatrzona jest niezwykle hermetycznym wstępem filozoficznym. O dziele tym pisałem już w książce Antropologia mimesis ${ }^{2}$, odczytując wybrane motywy przez pryzmat wypracowanej przez Benjamina w latach trzydziestych koncepcji mimesis. W niniejszym artykule spróbuję zinterpretować to dzieło w świetle teorii melancholii, odnosząc się pośrednio do ustaleń szeroko pojętej psychoanalizy (zwłaszcza jej twórcy Zygmunta Freuda). Benjamin wypracowuje własne pojęcie melancholii w kontekście analizy barokowego dramatu żałobnego, które nie odsyła jak u Freuda jedynie do psychologii indywidualnej, ale odnosi się również, a właściwie przede wszystkim do psychohistorii, estetyki i teologii. $W$ artykule pominę omówienie

1 W. Benjamin, Źródło dramatu żałobnego w Niemczech, przeł. A. Kopacki, Warszawa 2013.

2 R. Michalski, Antropologia mimesis. Studium myśli Waltera Benjamina $i$ Theodora W. Adorna, Wyd. Rolewski 2008. 
ewolucji znaczenia terminu "melancholia” w tradycji europejskiej. Zadanie to zostało już wykonane w szeregu opracowań, z których szczególnie polecam dwa: rozprawę Saturn i melancholia ${ }^{3}$, którą bezpośrednio inspirował się sam Benjamin oraz książkę Jennifer Radden The nature of melancholy 4 , zawierającą syntetyczne omówienie tej problematyki od starożytności po współczesne interpretacje tego pojęcia. W konstrukcji teoretycznej Benjamina melancholia wiąże się z poetyką alegorii na poziomie estetycznym i teologicznym. Obydwa poziomy odsyłają zaś do filozofii języka, której podstawą jest osobliwa wykładnia biblijnego mitu o Adamowym rajskim języku imion i o katastrofie wieży Babel. Ten kontekst omówiłem szczegółowo we wspomnianej już książce ${ }^{5}$, dlatego tutaj naszkicuję jedynie najważniejsze tezy niezbędne dla zrozumienia wywodów Benjamina. Niniejszy tekst zostanie uzupełniony drugim, ściśle z nim powiązanym artykułem, który będzie omawiał koncepcję alegoryczności. Pokażę w nim, w jaki sposób alegoreza zostaje zinterpretowana przez Benjamina jako językowa praktyka, która umożliwia przezwyciężenie melancholii obezwładniającej całe uniwersum barokowego dramatu ${ }^{6}$.

Punktem wyjścia interpretacji zaproponowanej w niniejszym artykule chciałbym uczynić spostrzeżenie Elizabeth Stewart, która wskazuje, że rozprawę Benjamina można odczytać również jako reakcję na doktrynę suwerenności zaprezentowaną przez Carla Schmitta ${ }^{7}$. Obydwaj myśliciele wychodzą od pesymistycznej diagnozy współczesności, choć ukazują ją przy użyciu różnych języków pojęciowych i inaczej rozkładają momenty krytyczne. Obydwaj fascynują się procesem sekularyzacji oraz konsekwencjami rozpadu porządku normatywnego, który prowadzi do anomii, chaosu i anarchii, a tym samym do wyłonienia się kruchego i podatnego na zranienia ludzkiego życia, życia pozbawionego jakiejkolwiek prawnej ochrony. Dla obydwu myślicieli groźba upadku oficjalnego ładu stawała się szczególnie wyraźna w sytuacji kryzysu demokracji parlamentarnej Republiki weimarskiej. Obydwaj byli więc szczególnie wyczuleni na moment katastrofy cywilizacyjnej, proponując jednak inne drogi wyjścia z tej sytuacji. Schmittiańską odpowiedzią na groźbę chaosu była koncepcja suwerena. Benjamin, pisząc o baroku, dostrzegał analogie między sytuacją kryzysową jaka zaistniała w XVII wieku, a stanem współczesnego kryzysu polityczno-cywilizacyjnego. W okresie wojny

3 R. Klibansky, E. Panofsky, F. Saxl, Saturn i melancholia, Studia z historii, filozofii, przyrody i medycyny, religii oraz sztuki, przeł. A. Kryczyńska, Kraków 2009.

4 J. Radden, The nature of melancholy. From Aristotle to Kristeva, Oxford 2000.

5 R. Michalski, Antropologia mimesis..., op. cit., s. 33-81.

6 Tytuł planowanego artykułu: Ocalenie z żałości. Waltera Benjamina koncepcja alegorii.

7 E. Stewart, Catastrophe and Survival. Walter Benjamin and Psychoanalysis, New York 2010. 
trzydziestoletniej doszło do redefinicji pojęcia władzy suwerennej, dawne teokratyczne rozumienie władzy zastąpiła idea monarchii absolutnej. Monarcha stawał się autokratą - był ustawodawca, wykonawcą ustaw oraz najwyższym sędzią, nie podlegał żadnej kontroli i za swoje rządy przed nikim nie był odpowiedzialny. W monarchii absolutnej władza zwierzchnia była nieograniczona przez kościól, stany i prawo. Uznawano, że wywodzi się ona bezpośrednio od Boga, stąd struktura władzy miała opierać się na ładzie boskim. Kierował nim król, będący symbolem rozumu niedostępnego innym poddanym. W konsekwencji monarcha absolutny był utożsamiany z państwem („,państwo to ja”). Ta idea monarchii absolutnej, która zdaniem Benjamina znalazła swój estetyczny wyraz $\mathrm{w}$ niemieckim dramacie żałobnym, odpowiada idei suwerena, jaką zaprezentował Schmitt w Teologii politycznej. Według Schmitta każda epoka historyczna posiada właściwy dla niej metafizyczny obraz świata. Jego struktura odzwierciedla się w strukturze odnoszącej się do niego formy politycznej organizacji ${ }^{8}$. Według Benjamina strukturę metafizycznego obrazu świata w czasach baroku oddawała melancholia, która w skróconej formie reprezentowała zarówno stan umysłu jednostek związanych z centrum władzy (suweren, dworski intrygant, alegorysta), jak i stan całego uniwersum doświadczany w skrajnych momentach indywidualnej i zbiorowej historii (wojna, upadek władzy, melancholijna kontemplacja, szaleństwo, męczeństwo etc.). Schmittiański suweren to ktoś, kto decyduje o tym, czy wystąpiła sytuacja wyjątkowa, a zarazem o metodach jej przezwyciężania9. Jego decyzja zawiesza cały dotychczasowy porządek prawny, wprowadzając nowy ład dla ocalenia instytucji państwa. Jednakże suwerenna władza, jak pisze czołowy teoretyk prawa trzeciej Rzeszy ,[...] nie jest wcale monopolem stosowania przymusu ani monopolem panowania, lecz dokładnie wyłącznością na podejmowanie ostatecznych decyzji [...] i paradoksalnie władza nie potrzebuje prawa, by ustanowić porządek prawny"10. Schmitt przyjmuje, że istotne pojęcia z zakresu nauki o państwie stanowią zsekularyzowane pojęcia teologiczne. Również Benjamin doszukuje się ukrytych źródeł teologicznych w świeckich pojęciach, które jednak definiuja jego zdaniem, nie tylko wymiar prawno-polityczny, ale również obszar dyskursu estetycznego (piękno, symbol, aura, świeckie oświecenie etc.).

Według Schmitta stan wyjątkowy zarządzany przez suwerena ma analogiczne znaczenie jak cud $w$ naukach teologicznych ${ }^{11}$. Boska ingerencja $\mathrm{w}$ bieg ludzkiej historii, odrzucana przez oświeceniowych

8 C. Schmitt, Teologia polityczna, w: idem, Teologia polityczna i inne pisma, przeł.

M. A. Cichocki, Warszawa 2012, s. 86.

9 Ibidem, s. 46.

10 Ibidem, s. 52.

11 Ibidem, s. 77. 
deistów, odpowiada bezpośredniej ingerencji suwerena $\mathrm{w}$ obowiązujący porządek prawny. Suweren zarządzający kryzysem i na mocy absolutnej, niczym nieskrępowanej decyzji przeciwdziałający katastrofie, osuwaniu się państwa w stan kompletnej anomii i chaosu, staje się tym samym figurą zsekularyzowanego cudotwórcy. Cud suwerennej władzy ustanawia nowy porządek normatywny, ale również nową nieskonfliktowaną i decyzyjną formę tożsamości, którą odzwierciedla dyktator, absolutna, omnipotentna podmiotowość. Benjamin, pisząc swoją rozprawę, poddaje krytyce takie rozwiązanie, dostrzega $\mathrm{w}$ nim ryzyko otwarcia drogi prowadzącej wprost do narodzin bezwzględnej autorytarnej władzy oraz do powstania podmiotowości opętanej fałszywym obrazem własnej wszechmocy. Suweren ukazany w barokowym dramacie żałobnym pokazuje konsekwencje, jakie mogą płynąć z praktycznej realizacji idei Schmitta. Benjamin nie oferuje jednak w analizowanym tekście mocnej alternatywy dla propozycji autora Teologii politycznej, lecz pozostawia czytelnikowi nikłą mesjanistyczną nadzieję, jaka może obudzić się bez pośrednictwa transcendentnej łaski czy cudu w sferze immanencji porażonej widmem katastrofy, a zatem w stanie dogłębnej melancholii osnuwającej mroczną aurą zarówno świadomość melancholika, jak i doświadczany przez niego świat. W tym kontekście istotnego znaczenia nabiera pojęcie alegorii i alegorezy, które wykracza daleko poza techniczne ramy poetyki i zaczyna pełnić funkcję quasi-soteriologicznego środka w walce o ocalenie ze stanu permanentnego upadku i anomii. Nie tyle więc polityka i prawo, ile estetyka staje się główną dziedzina, w której Benjamin tropi symptomy procesu sekularyzacji teologii. Barokowa poetyka dramatu żałobnego stanowi dla niego reprezentatywny przykład początkowej fazy tego procesu. Podmiot sceniczny przeżywa tutaj rozmaite patologiczne objawy spowodowane napięciem między czyhającą zewsząd katastrofą a "cudownymi" (w sensie Schmittiańskim) mocami absolutnej suwerenności, która nieudolnie próbuje zapanować nad stanem kryzysu. W większości przypadków najważniejsze dramatis personae doświadczają nieuchronnej klęski, jednak na scenie dramatu zdarzają się również przebłyski kruchej nadziei, momenty nagłego skoku ku ocaleniu, w których ujawnia się ukryta głębia alegoryzującej świat melancholii. Co najważniejsze, zbawienie podmiotowości nie dokonuje się tutaj, zdaniem Benjamina, za pośrednictwem „,cudu” obdarzającego jednostkę absolutną suwerennościa lecz na mocy dialektycznego ruchu, w którym podmiotowość melancholijnie „zanurza się" w świat rzeczy opróżnionych z obiektywnego sensu, a zarazem - w tym właśnie akcie powrotu do stanu Stworzenia (=nagiego życia) - odnajduje ona iskrę mesjańskiej nadziei. Artykuł podejmuje próbę opisania tej dialektyki w ścisłym powiązaniu z poetyką alegorii, która w dramacie żałobnym funkcjonuje jako główne "estetyczne narzędzie" pozwalające podmiotowości wydobyć się 
na chwilę ze stanu upadku. Melancholia to odpowiedź na katastrofę obiektywną i subiektywną. Dramat żałobny przedstawia różne warianty reakcji na stan anomii i chaosu, które, zdaniem Benjamina, odsłaniają źródłową ideę tego gatunku dramatycznego.

Kończąc uwagi wstępne, podkreślmy, że wbrew klasycznemu już rozróżnieniu Freuda Benjamin używa zamiennie terminu melancholia i żałoba. W największym skrócie żałoba i melancholia różnią się, według twórcy psychoanalizy, stosunkiem do utraconego obiektu. Obydwa schorzenia są bardzo podobne do siebie $\mathrm{w}$ fazie początkowej, pojawia się w nich bowiem utrata zainteresowania zewnętrznym światem, utrata zdolności wyboru jakiegokolwiek obiektu miłości etc. Jednak osoba poddana żałobie po pewnym czasie zaczyna akceptować stratę, uczy się kierować swoją energię libidalną na inne obiekty i ostatecznie podporządkowuje się wymogom rzeczywistości. Melancholik nie powraca do życia, od samego początku występuje u niego nieobecny w żałobie symptom polegający na natarczywym samooskarżaniu się, które stopniowo doprowadza Ja do autodegradacji. Jak pisze Freud „W wypadku żałoby to świat zubożał i opustoszał - w wypadku melancholii zubożało i opustoszało samo ja"12. Melancholik w przeciwieństwie do żałobnika nie potrafi uświadomić sobie, co właściwie utracił, ponieważ, jak przekonuje Freud, doszło u niego do nieświadomego utożsamienia się z obiektem, na skutek czego jego Ja rozpada się na dwie części, z których jedna wchodzi w rolę instancji oskarżającej, druga zaś - nieustannie dezawuowanego obiektu. Dawna miłość do utraconego obiektu przekształca się $\mathrm{w}$ nienawiść do samego siebie. Utrata obiektu zamienia się tym samym w utratę Ja.

Barokowa żałość łączy w sobie elementy melancholii i żałoby, nie odnosi się jednak wyłącznie do stanu psychologicznego, ale odsyła również do natury samej filozofii, ujawnia mechanizmy tworzące estetyczną konstrukcję dramatu, a ponadto określa metafizyczny obraz świata charakterystyczny dla XVIII wieku. Melancholia stanowi, według Benjamina, centralny fenomen, a zarazem jedną z podstawowych idei barokowego dramatu żałobnego.

Jej filozoficzną wartość można dostrzec nawet wówczas, gdy ograniczymy ją do stanu psychicznego. Już $w$ tym wąskim rozumieniu przejawia się ona jako szczególne nastawienie poznawcze, w którym podmiot dezawuuje obowiązujące struktury sensu przypisywane obiektywnej rzeczywistości i samemu podmiotowi. Melancholia daje ponadto możliwość przekroczenia granicy pomiędzy tym, co zewnętrzne i wewnętrzne, a przede wszystkim zaciera granicę między życiem i śmiercią do której odsyłają tradycyjne wyobrażenia metafizyczne. Wszystkie

12 S. Freud, Żałoba i melancholia, w: idem, Psychologia nieświadomości, przeł. R. Reszke, Warszawa 2009, s. 149. 
wymienione powyżej psychologiczne aspekty melancholii uznawane przez psychoanalizę za symptomy patologii zawierają implikacje natury filozoficznej, które Benjamin wykorzystuje w swoich dociekaniach. Melancholia staje się $\mathrm{w}$ jego wykładni nastrojem definiującym postawę filozofa, a jednocześnie ideą estetyczną organizującą świat przedstawiony w dramacie żałobnym. Podobnie jak Freud podkreśla on związek melancholii z utratą cennego obiektu i z wyraźnym deficytem języka, który zatraca stopniowo zdolność do artykułowania sensu zrozumiałego w obiegowej komunikacji. Niemota, zahamowanie zdolności komunikacyjnych charakteryzuje, zdaniem Benjamina, nie tylko melancholika, ale jest ponadto wszechobecną formą ekspresji natury, jeśli spojrzeć na nią z perspektywy teologicznej.

Już w swojej wczesnej rozprawce $O$ języku w ogóle i o języku człowieka Benjamin zauważa, że smutek jako ekspresja braku przenika cały stworzony świat rzeczy:

Jednakże po Upadku, gdy słowo Boga przeklęło ziemię, wygląd natury uległ głębokiej zmianie. Teraz rozpoczyna się inna jej niemota, ta, którą mamy na myśli, mówiąc o głębokim smutku natury. Jest metafizyczną prawdą, że cała natura poczęłaby się skarżyć, gdyby użyczono jej języka. [...] Skarga jest jednak najbardziej niezróżnicowanym, bezsilnym wyrazem języka, zawiera niemal wyłącznie zmysłowe tchnienie; i tam, gdzie szumią tylko rośliny, zawsze pobrzmiewa skarga ${ }^{13}$.

Podobna idea pojawia się również w rozprawie o dramacie żałobnym, w której Benjamin utrzymuje, że melancholia przenika całe uniwersum barokowego dramatu, sygnalizując rozpad panującego porządku. Jako symptom głębokiego zwątpienia w sens świata może ona prowadzić do katastrofy, ale również otwierać przestrzeń prawdy i nadziei. Ta ambiwalencja, a właściwie dialektyka upadku i ocalenia będzie głównym przedmiotem poniższych analiz. W pierwszej części przedstawię bardziej szczegółowo Benjaminowskie ujęcie żałości w kontekście psychoanalizy (1), następnie omówię główne formy reakcji na melancholijne doświadczenie utraty ukazane paradygmatycznie w postaciach: tyrana (2), męczennika (3) i ducha-zjawy (4). Koncepcja alegoryczności stanowiąca klucz do zrozumienia pozytywnego aspektu melancholii zostanie poddana analizie w drugim artykule, który można uznać za bezpośrednią kontynuację niniejszego tekstu.

13 W. Benjamin, O języku w ogóle i o języku człowieka, w: idem, Konstelacje. Wybór tekstów, przeł. A. Lipszyc, A. Wołkowicz, Kraków 2012, s. 15-16. 


\section{Melancholia jako nostalgia za utraconym obiektem}

Jak wspomniałem we wstępnych uwagach, podstawowym doświadczeniem melancholijnej żałości jest utrata obiektu. Benjamin uwypukla w swoich analizach implikacje tej utraty, które są widoczne na planie estetycznym (struktura kompozycji dramatu), psychologicznym (dekompozycja podmiotowości) i w wymiarze języka. Związek melancholii z zubożeniem języka możemy wyjaśnić, odwołując się do tradycji psychoanalitycznej (Lacan, Kristeva, Klein). Podkreśla się w niej, że praca żałoby polega na opanowaniu utraty dzięki transformacji utraconego obiektu (osoby) w symbol. Moment, w którym jego nieobecność dla podmiotu zostaje $\mathrm{w}$ pełni zaakceptowana, wskazuje na to, że utracony obiekt zyskuje wymiar symboliczny, tracąc charakter realnego przedmiotu pragnienia. Utrata stanowi więc warunek konieczny dla procesu konstytuowania się języka.

W melancholii związek z utraconym obiektem jest natomiast na tyle silny, że melancholik nie potrafi go odrzucić, nawet dla celu symbolizacji. Innymi słowy, w wyniku narcystycznej inkorporacji obiektu ${ }^{14}$ podmiot traci dystans niezbędny do tego, aby uczynić go przedmiotem swojej wypowiedzi, aby wyartykułować go w języku. Melancholia prowadzi zatem do zubożenia lub zniekształcenia zdolności komunikacyjnych.

We wspomnianym już artykule Żałoba i melancholia Freud podkreśla, że chory na melancholię nie jest w stanie uświadomić sobie, co stracił, a jeśli nawet „,...] zdaje sobie sprawę, kogo stracił, nie potrafi jednak stwierdzić, co oznacza ta utrata"15. Ta niemożność uświadomienia sobie utraty obiektu wynikająca z uprzedniej identyfikacji powoduje poważne zakłócenia osobowości chorego. Jednakże w późniejszym artykule Ja i to Freud łączy melancholię z procesem kształtowania się podmiotowości, modyfikuje więc swoją wcześniejszą koncepcję, wskazując, że wyrzeczenie się utraconego obiektu przez id musi być poprzedzone identyfikacją z utraconym obiektem (wcześniej była ona uznana za patologiczny symptom melancholii). Przekierowanie energii libidalnej zwróconej ku obiektowi w energię narcystyczną (inkorporacja obiektu) ułatwia bowiem wyrzeczenie się tego obiektu przez id, a zarazem umożliwia instancji Ja dokonanie aktu sublimacji, tzn. pozwala jej wyznaczyć inne cele dla energii popędowej. Freud dochodzi ostatecznie do wniosku, że na podłożu kolejnych doświadczeń utraty i wyrzeczenia się obiektu za pośrednictwem uprzedniej identyfikacji z nim formuje się charakter $\mathrm{Ja}^{16}$. Melancholijne utożsamienie się z utraconym obiektem staje się więc, we-

14 S. Freud, Żałoba i melancholia..., op. cit., s. 152.

15 Ibidem, s. 149.

16 S. Freud, Ja i to, w: idem, Psychologia nieświadomości, op. cit., s. 149. 
dług nowej hipotezy, warunkiem konstytuowania się ludzkiej podmiotowości - idea ta stanowi jedną z ważniejszych przesłanek analiz Benjamina, chociaż prawdopodobnie nie inspirował się on w tym przypadku psychoanalizą.

Dramat żałobny ukazuje rozmaite manifestacje i symptomy utraty, ale nigdzie wyraźnie nie wskazuje jej obiektu. W tym sensie na płaszczyźnie estetycznej wiernie odtwarza stan melancholii; można nawet powiedzieć, że wewnętrzna struktura tego gatunku dramatycznego pokrywa się ze strukturą samej melancholii. Trauerspiel to niejako melancholia w skali mikro- i makrokosmicznej, ponieważ symptomy utraty nie dotyczą tylko przedstawionych $\mathrm{w}$ nim postaci, ale również całego barokowego uniwersum, łącznie z kolektywną historią i naturą.

Benjamin uwypukla w swojej interpretacji fakt, że w baroku zachodzi gwałtowna zmiana paradygmatu wiedzy - starożytny ideał episteme ustępuje obrazowi poznania jako wiedzy eksperymentalnej prowadzącej do przekształcenia świata na użytek człowieka oraz transformacja ustroju politycznego - teokratyczne państwo zostaje zastąpione absolutystyczną monarchią. Co ważniejsze, barok osadzony silnie w religijności chrześcijańskiej przeżywa utratę eschatologicznej nadziei, całościowy teologiczny obraz uniwersum rozpada się, astronomia odkrywa bezbrzeżne przestrzenie kosmosu, Ziemia, a wraz z nią człowiek, traci centralną pozycję w kosmicznym ładzie, dominować zaczyna wyobrażenie Boga jako Deus absconditus, niepoznawalnego, nieprzewidywalnego stwórcy ${ }^{17}$, szczególnie obecne w protestantyzmie, który odbiera wszelką wartość ludzkim uczynkom, porzuca ideę łaski na rzecz przykazania wiary i doktryny predestynacji. Transcendencja staje się niedostępna do tego stopnia, że $\mathrm{w}$ religijnym imaginarium tych czasów usuwane są wszelkie wyobrażenia na jej temat, naczelną zasadą staje się starotestamentowy zakaz czynienia podobizn.

Religijny człowiek baroku tak kurczowo trzyma się świata, bo czuje, że wraz z nim dryfuje ku katarakcie. Nie istnieje eschatologia barokowa [...] Tamten świat zostaje opróżniony ze wszystkiego, w czym drży choćby najlżejsze tchnienie doczesności [...] niebo jako pustka ma stać się zdolne do tego, by kiedyś mocą katastrofy zniszczyć ziemię jako taką ${ }^{18}$.

17 Por. H. Blumenberg, Legitimität der Neuzeit, Frankfurt am Main 1988.

18 W. Benjamin, Źródło dramatu żałobnego..., op. cit., s. 65 . W tym fragmencie do głosu dochodzi niewątpliwie judaistyczny wątek interpretacji Benjamina. Christine Buci-Glucksamann w swojej książce Baroque Reason zauważa, że mistyczno-mesjański nurt judaizmu reprezentowany zwłaszcza przez Gershoma Scholema, przyjaciela Benjamina, kładł nacisk na katastroficzny wymiar historii oraz obecny w niej moment utopii. Odkupienie postrzegano tej perspektywie jako niestrudzone oczekiwanie na Mesjasza. Podkreślano nieskończoną przepaść między czasem obecnym (olam hazeh) a czasem, który nadchodzi (olam haba), który może ujawnić się w serii katastrof 
Barokowy dramat żałobny ukazuje wszechobecny stan anomii. Zmienność, przemoc występująca w sferze obiektywnej wpływa na jednostkę, wpisuje się niejako w jej cielesne reakcje, w psychodynamikę stanów emocjonalnych. Podobnie jak u Freuda psychiczne symptomy chorych na nerwicę odzwierciedlają tanatyczne procesy zachodzące podskórnie $\mathrm{w}$ ich nieświadomości, tak u Benjamina reakcje, przeżycia głównych postaci dramatu żałobnego stanowią wyraz tanatycznych tendencji przejawiających się w kolektywnej nieświadomości „podmiotu" historii. Wojny na tle religijnym, konflikty, zmiany ustroju, „obiektywne" procesy dziejowe opisywane przez klasyczną historiografię kryją w sobie wyparte "historyczne podziemie”, które powinien odsłonić, a właściwie skonstruować krytyczny historyk. Benjamin obiera za przedmiot swojej „obiektywnej interpretacji” fenomenów historycznych ignorowaną lub dezawuowaną przez klasyczne literaturoznawstwo formę dramatyczna, dostrzegając w niej rodzaj „estetycznej soczewki”, która skupia w sobie promienie tworzące metafizyczny obraz świata w dobie baroku. Przy czym apodyktycznie stwierdza: „Treścią tego dramatu, jego prawdziwym przedmiotem, jest życie historyczne, takie, jakim przedstawiała je sobie owa epoka"19. Psychofizyczne symptomy, a nawet sensomotoryczne reakcje bohaterów dramatu żałobnego odtwarzają bezwiednie wstrząsy zachodzące na planie historycznym. Benjamin zakłada, że zarówno jednostkowa, jak i kolektywna historia oraz pamięć są analogiczne w swojej strukturze. Trauerspiel stanowi zatem monadyczny obraz, który w skróconej formie przedstawia wizję całości barokowego uniwersum ${ }^{20}$.

(wojen, rewolucji, klęsk głodu etc.). Oczekiwane „całkiem nowe” miało nadejść jako nieprzewidywalne, gwałtowne wtargnięcie mesjańskiego wymiaru w kontinuum historii. Jak stwierdza Scholem: „Żydowski mesjanizm jest w swoich źródłach i ze swej natury - tego nie da się wystarczająco dobitnie podkreślić - teorią katastrofy, katastroficznego elementu w przejściu od historycznej teraźniejszości do mesjanistycznej przyszłości" (G. Scholem, The Messianic Idea in Judaism and Other Essays in Jewish Spirituality, New York 1971, s. 7). W żydowskim mesjanizmie brakuje zatem jakiejkolwiek idei historycznego postępu. W tej pesymistyczno-krytycznej wizji rzeczywistości nadejście Mesjasza, odkupienie lub - w terminologii kabały Izaaka Lurji - „restytucja świata” tworzy niedającą się zniwelować przepaść między historią opresji ludu żydowskiego a historią mesjańskiej wolności. Przejście z jednego wymiaru historii do drugiego dokonać się może, jak w zgodzie z tą tradycją podkreśla Benjamin, jedynie za pośrednictwem jakościowego skoku. Analizując barokowy, na wskroś chrześcijański dramat żałobny, niemiecki myśliciel odsłania w niej zatem ideę mesjańskiego judaizmu. Ten paradoks może stanowić obiekt zasadnej krytyki jego przedsięwzięcia, którą z powodu ograniczeń ramowych pominiemy w tym artykule. Por. Ch. Buci-Glucksamann, Baroque Reason. The Aesthetics of Modernity, London 1994, s. 63.

19 W. Benjamin, Źródło dramatu żałobnego..., op. cit., s. 59.

20 Podobne założenie znajdujemy również u późnego Freuda poszukującego strukturalnych analogii między wymiarem psychologii jednostkowej i psychologii 
W tej wizji znika bezpośredni dostęp człowieka do transcendencji, dzieje tracą jednolity nadrzędny cel. Wszelkie działania, zdarzenia zamykają się w immanentnym wymiarze doczesności. Wszechobecne, melancholijne poczucie utraty czegoś, czego nie można sobie w pełni uświadomić, najwyraźniej przejawia się w utracie nadziei eschatologicznej, która w średniowieczu tworzyła linearną narrację o zbawieniu. Niemiecki dramat potęguje to odczucie do tego stopnia, że „,[...] całkowicie pogrąża się w beznadziejności kondycji ziemskiej", nieprzytomnie ucieka „,[...] w nieuświęcony łaską świat natury"21. W efekcie historia zamienia się w naturohistorię (Naturgeschichte), w powtarzalny, przypadkowy rytm zdarzeń pozbawiony jakiegolwiek celu. Wizja ta ukazana jest na scenie królewskiego dworu. Losy bohaterów dramatu żałobnego przedstawione w alegorycznym skrócie nie tworzą żadnej ciągłości, lecz przekształcają się w zawrotną kombinatorykę heterogenicznych scen - obrazów. Główne postaci zaplątane w gęstą sieć dworskich intryg, machinacji i knowań giną z ręki swoich rywali lub podwładnych, a na ich miejsce pojawiają się inni, którzy kończą podobnie. Powtarzalne sekwencje obrazów, cykle melancholijnego przygnębienia i hedonistycznego szału rozbijają linearność biegu zdarzeń, która mogłaby wskazywać na jakikolwiek zewnętrzny cel i łudzić symbolicznym pozorem całości ${ }^{22}$.

W ten sposób niemiecki dramat barokowy, podobnie jak Freudowski żałobnik, nieustannie odtwarza i powtarza uwarunkowania, które określiły jego powstanie. Polityczne katastrofy, przemoc, brak stabilności, śmierć, walka o władzę oraz jej upadek określające bieg historii przenoszą się na scenę i na skutek swojej powtarzalności tracą charakter powagi, stają się figurami beznadziejnej, przepełnionej smutkiem i lamentem gry, ponurej groteski przywodzącej na myśl teatr lalkowy. Dramat żałobny próbuje wypełnić wszechogarniającą pustkę, bezcelowość nadmiarem ekspresji, ostentacyjnościa, wybujałym językiem i bombastycznościa, dlatego smutek, rozpacz miesza się tutaj często z komizmem. Postaci działaja jakby były powodowane przymusem powtarzania, nawet celowe, czysto instrumentalne działania bohaterów kojarzą się bardziej z czynnościami perseweracyjnymi aniżeli z świadomym aktami suwerennych jednostek.

Doświadczeniu bezsensu świata towarzyszy tutaj przeżycie wewnętrznej pustki. Dramatyczna żałość łączy zatem w sobie momenty Freudowskiej melancholii (pustka wewnętrzna) i żałoby (pustka świata). Metaforą oddającą obydwa aspekty żałości jest maska. "Żałość to taka postawa, kiedy uczucie nakłada spustoszonemu światu maskę i w ten sposób na nowo go ożywia, aby na jego widok zaznawać zagadkowej

zbiorowości.

${ }^{21}$ W. Benjamin, Źródło dramatu żałobnego..., op. cit., s. 86.

22 Ibidem, s. 232. 
satysfakcji." ${ }^{23} \mathrm{~W}$ istocie światu zostaje nałożona teatralna maska śmierci będąca obrazem utraty czegoś, co być może nigdy nie było przedmiotem doświadczenia, a teraz objawia się jako martwa pozostałość, ślad wskazujący nie tyle na utracony obiekt, ile na jego brak. Tak pojęty stan żałości znajduje swój najpełniejszy wyraz w postaci alegorysty. To on właśnie praktykuje widzenie świata jako maski kryjącej w sobie rozproszone fragmenty znaczenia, które usiłuje następnie ułożyć w znaczące konfiguracje i rozszyfrować24. Melancholijny alegorysta usiłuje ożywić opróżniony z sensu świat rzeczy i własną duszę w inny sposób niż czyni to Freudowski żałobnik. Barokowa żałość ucieleśniona w jego praktyce ożywia świat nie dzięki akceptacji utraty obiektu, ale dzięki nieustannemu przywoływaniu go.

Obraz maski w kontekście utraty odsyła więc raczej do Freudowskiej koncepcji melancholii, aniżeli żałoby, przy czym nie pojawia się tutaj negacja wewnętrznej pustki (samooskarżenia Freudowskiego melancholika), lecz próba jej opanowania w akcie odszyfrowania nieczytelnych śladów pozostawionych przez utracony i nieznany obiekt. Według Freuda melancholik i żałobnik stoją przed tą samą alternatywą: być lojalnym wobec rzeczywistości albo wobec utraconego obiektu. Pierwszy wariant wybiera żałobnik, drugi zaś melancholik. Praca żałoby polega $\mathrm{w}$ pewnym sensie na ponownym symbolicznym uśmierceniu tego, co już jest nieżywe dla żałobnika (utracony obiekt). Dopiero dzięki temu aktowi destrukcji podmiot może uwolnić się od widma przeszłości i powrócić do życia. Natomiast melancholik internalizuje obiekt, który staje się niejako jego własnym obcym ciałem, które próbuje upokorzyć, ale od którego nie potrafi się uwolnić. Pomimo wewnętrznego antagonizmu i spowodowanego nim cierpienia melancholik porzuca świat i pozostaje wierny wobec utraconego obiektu. To jest główny powód, dla którego Freud uznaje melancholię za formę patologii, żałobę zaś za przejaw zdrowej postawy psychicznej. Benjamin widzi ten problem inaczej. Patologiczne jest dla niego raczej porzucenie utraconego obiektu postrzegane jako rodzaj zdrady. W żałości nie chodzi bowiem o opanowanie straty, o pogodzenie się z nią, lecz o głęboką artykulację śladów pozostawionych przez utracony obiekt. Ta wierność wobec utraconego obiektu, nieustanne zmaganie się z jego widmową obecnością staje się naczelnym etycznym imperatywem Benjaminowskiego melancholika. Obrana przez niego droga obciążona jest jednak podwójnym ryzkiem, uwidocznionym przez dwie postaci: męczennika pogrążającego się we wzniosłej autodestrukcji oraz tyrana ulegającego iluzji omnipotencji, który z powodu niezdolności do podejmowania decyzji wchodzi ostatecznie $\mathrm{w}$ rolę męczennika.

23 Ibidem, s. 177.

24 Por. R. Michalski, Antropologia mimesis..., op. cit., s. 70-82. 


\section{Tyran i apoteoza władzy absolutnej}

Benjamin podkreśla, że postaci tyrana i męczennika stanowią niejako dwie strony tej samej monety, łączą ich bowiem dwie zasadnicze cechy: męczeńska śmierć w kontekście religijnym oraz wytrwałość - u pierwszego: $\mathrm{w}$ dobrowolnym znoszeniu tortur, $\mathrm{u}$ drugiego: $\mathrm{w}$ walce o koronę. Tyran dąży do przywrócenia ładu w stanie wyjątkowym, podczas gdy męczennik posiadający tutaj cechy stoickiego mędrca inkorporuje poniekąd stan wyjątkowy do swojego wnętrza miotanego burzą afektów. ${ }^{25}$ Męczeństwo władcy ukazane $\mathrm{w}$ barokowym dramacie żałobnym stanowi osobliwą świecką transfigurację pasji Chrystusa: „Tak jak Chrystus król cierpiał w imię ludzkości, tak wedle poglądu barokowych pisarzy cierpi majestat jako taki"26. Męczennik zwraca się ku Bogu, ku transcendencji, ponieważ świat doczesny stanowi dla niego otchłań oddaloną od boskiego porządku, cierpienie tyrana polega zaś na jego nieuchronnym upadku w skorumpowany, przemijalny świat. Najważniejszą cechą barokowego męczennika jest stałość (constantia), która pomaga mu wytrwać w kaźni. Sensem jego działania polegającego najczęściej na biernym oporze jest uznanie ze strony Boga, zdobycie korony męczeństwa. Tyran z kolei przejawia frenetyczną aktywność, dążąc w makiawelicznym duchu do zdobycia i podtrzymania władzy, ta jednak nie służy, jak u Makiawellego stabilizacji państwa, lecz jego własnym partykularnym interesom. Barokowi tyrani przejawiają często skłonność do realizacji erotycznych, przepełnionych afektami celów (Schach Abas w Catharina von Georgien Andreasa Gryphiusa, Herodes w Johanna Christiana Hallmanna Marianne). Postawa męczennika wymaga natomiast stoickiej kontroli afektów. Stałość męczennika stoi więc w opozycji do nieustępliwości (pertinacia) tyrana.

W obydwu postaciach znajduje swój wyraz zaburzenie kolektywnego poczucia stabilnej rzeczywistości. Trauerspiel ukazuje historię pozbawioną celu, świat opróżniony z obiektywnego sensu, w którym boska opatrzność staje się nieprzenikniona. Doświadczenie utraty substancjalnych podstaw uniwersum i wszelkich metafizycznych zabezpieczeń, które w średniowieczu dawały człowiekowi pociechę, uwalnia lęk przed terrorem nieprzewidywalnego fatum. Tyran neutralizuje ten lęk za pośrednictwem graniczącej $\mathrm{z}$ sadyzmem potrzeby władzy, męczennik zaś broni się przed nim, popadając w masochistyczną autodestrukcję. Psychologicznym korelatem stanu powszechnej anomii jest psychiczne rozproszenie, połączone z symptomami depersonalizacji, derealizacji i amnezji. Najjaskrawszy wyraz tego stanu reprezentuje figura tyrana męczennika. Jego cierpienia są symptomem napięcia między religijną

25 W. Benjamin, Źródło dramatu żałobnego..., op. cit., s. 77.

26 Ibidem, s. 75. 
żarliwością a absolutystyczną władza, która daje mu nieomal boskie prerogatywy. Gdy jego dążenia motywowane pobudkami religijnymi zostają zahamowane w wyniku uwikłania w mechanizmy władzy, jego energia psychiczna ulega rozproszeniu i kieruje się w stronę fizyczności. Rezultatem tego przekierowania energii jest obsesja na punkcie cielesności. Dramat żałobny lubuje się w ostentacyjnych przedstawieniach fizycznego bólu i psychicznego cierpienia, które wyraża się w gwałtownej, przesadnej ekspresji. Paraliż, konwulsyjne erupcje emocji, bezustanne załamywanie rąk, egzaltacja stają się naocznym dowodem tego, że ciało bez reszty podlega rozkładowi, nieuchronnej przemijalności i nie może funkcjonować jako niepatologiczne pole wyrazu dla „metafizycznych impulsów". Tyran zakleszczony między stłumioną ale wciąż żywą potrzebą zbawienia, potrzebą kontaktu z transcendencją a wymogami narzucanym przez instytucję władzy absolutnej zamienia się w męczennika, w oniemiałego świadka wspólnej martyrologii ludzkości pozbawionej eschatologicznej nadziei oraz natury ograbionej z suwerennego znaczenia i przekształconej w obiekt manipulacji. Jako domniemany władca stworzenia sam podlega kondycji tego, co stworzone „suweren jest panem stworzeń, ale też sam stworzeniem pozostaje" Tyran pogrąża się w stanie stworzenia (=nagiego życia), które w tym przypadku ujawnia się w jego braku decyzyjności. Klęska kalkulującego rozumu oddaje go w posiadanie nagich, niekontrolowanych afektów, dlatego „,[...] we władcy, tym arcywzniosłym stworzeniu, może obudzić się zwierzę o niepojętej mocy." ${ }^{28}$ Królowie jako męczennicy popadają w szaleństwo, którego siła jest wprost proporcjonalna do wysokości pozycji, jaką zajmują w hierarchii stworzenia. Najbardziej wywyższeni na ludzkim padole cierpią najgłębsze katusze, ich indywidualne cierpienie odzwierciedla rozpad symbolicznego porządku obiektywnej rzeczywistości, która zamienia się w chaotyczny, anomijny stan „nagiego życia”, życia czysto animalnego wyzutego z rozumności i praw, które ona ustanawia. Dlatego w dramatach traktujących o tyranie podkreśla się efekt niesamowitości związany z nagłym wyłonieniem się zwierzęcej mocy w cierpieniach oszalałego władcy. Żałość prowadzi tu do furii, a następnie do agonii. Tyran upojony iluzją omnipotencji redukuje zarówno ludzkie życie, jak i historię do teatru marionetek poddanych absolutnej kontroli. Jednakże to złudzenie obraca się wkrótce na jego niekorzyść. Okazuje się, że suwerenność zawodzi, ponieważ kryje w sobie fundamentalną sprzeczność polegającą na tym, że im bardziej suweren próbuje podporządkować sobie kontyngencję świata, tym więcej kontyngencji sam wytwarza. Tyran cierpi z powodu braku decyzyjności, uwikłany w antynomię bezgranicznej władzy i niezdolności do jej sprawowania

27 Ibidem, s. 92.

28 Ibidem, s. 95. 
popada na końcu w obłęd lub ginie z ręki swoich ofiar. Znakiem tej absolutnej w roszczeniach, choć bezsilnej w praktyce władzy jest korona, która osuwa się z głowy tyrana, $\mathrm{W}$ przeciwieństwie do bohatera tragicznego, którego suwerenność tkwi w jego decyzjach, tyran z Trauerspiel jest postacią niedecyzyjna, uosabiającą mizerię instytucji państwa. Historia drwi z jego suwerenności. Korona, szaty, berło - insygnia jego ziemskiej władzy okazują się nieznaczącymi kawałkami materii, zewnętrznymi oznakami wewnętrznej niemocy i marności. Suweren będący głównym reprezentantem historii stoi niejako na przecięciu dwóch sprzecznych tendencji: zbiorowej tęsknoty za pokojem i agonicznymi dążeniami rzeczywistości politycznej będącej domeną walki o władzę i śmierci.

Walka tyrana to walka o dziejowy ład, jego upadek to upadek historii, która przenika do dramatycznej akcji. Jego paraliż, melancholia, samobójcze myśli, absurdalne spazmy przemocy, lament, napuszone tyrady odzwierciedlają historyczne perturbacje. Suweren wraz ze swoim dworem zamienia się ostatecznie w zwłoki, co zwiastuje zbliżanie się dziejowej katastrofy. W pojedynku między podmiotem podtrzymującym za wszelką cenę iluzję suwerenności a kontyngencją przytłaczających go zdarzeń wygrywa ostatecznie bezcelowa historia, absurdalność przemocy i uniwersalność śmierci.

Cierpienia tyrana odzwierciedlają specyficzny model melancholii. W świetle psychoanalizy kontyngentną historię, która triumfuje nad tyranem, możemy zinterpretować jako zewnętrzny odpowiednik nieświadomych procesów powstałych na skutek bezwiednej identyfikacji podmiotu z utraconym obiektem. Suweren w dramacie żałobnym stanowi inkarnację historii, ale nie rozpoznaje tej prawdy o sobie i zmaga się beznadziejnie z dziejowym żywiołem, postrzegając go jako coś zewnętrznego. Melancholik Freuda działa na odwrót - walczy ze sobą, nie dostrzegając, że walczy w istocie z "Innym”, który stał się jego integralną częścią. $W$ obydwu modelach melancholik cierpi zatem z powodu swoistego qui pro quo, mylnie definiuje swojego „wroga”. Właściwym przeciwnikiem nie jest bowiem ani sam podmiot (melancholik Freuda), ani obiektywna historia (tyran), lecz wyparte roszczenia przeszłości, które domagają się artykulacji i urzeczywistnienia. Obydwaj nie słyszą stłumionych "głosów" skargi i prośby o ocalenie, dlatego ponoszą klęskę. Cierpienie nie rehabilituje ich ani nie uszlachetnia, prowadzi jedynie albo do masochistycznej autodeprecjacji, albo do równie poniżającego uwikłania w polityczne intrygi, spiski i knowania. Melancholia pierwszego z nich kończy się klęską podmiotu, drugiego zaś - odartą z wszelkiego majestatu fizyczną śmiercią. 


\section{Męczennik - martyrologia cielesności}

Inną reakcję obronną na melancholię przedstawia w dramacie żałobnym męczennik, który występuje najczęściej w dramacie martyrologicznym. $\mathrm{W}$ jego cierpieniu istotne jest to, że przeżywa on katusze $\mathrm{w}$ imię całego rodzaju ludzkiego, ignorując subiektywny, indywidualny ból. Poddawane torturom ciało męczennika reprezentuje poniekąd ciało wszystkich ludzi. Jego rany wystawione na publiczny widok, odsłonięte na spojrzenia innych stanowią ekwiwalent przeraźliwych okrzyków wewnętrznego, prywatnego bólu. Greckie słowo martyr, etymologiczne źródło niemieckiego der Märtyr, oznacza dosłownie „świadectwo”, „świadka”, co trafnie oddaje barokowe wyobrażenie męczeństwa - $\mathrm{w}$ dramacie żałobnym cierpienia męczennika dają bowiem świadectwo obecności Boga, a zarazem wymagają świadectwa innych. Taka publiczna artykulacja cierpienia staje się rodzajem ciernistej drogi prowadzącej do uniwersalnego zbawienia. Świadkowie gehenny męczennika doświadczają naocznie obecności sacrum i uzyskują $w$ ten sposób obietnicę ocalenia. Męczeństwo łączy w sobie zatem elementy etycznej postawy z wymiarem estetycznej spektakularności. Scena teatru oferuje idealną przestrzeń dla spektaklu męczeństwa, w którym chodzi o uwidocznienie rozdziału duszy i ciała - wystawione na widok, nękane spazmami bólu ciało symbolizuje marność doczesnego świata, podczas gdy dusza całkowicie oddzielona od cielesnych konwulsji zachowuje spokój i wytrwałość.

Dramat żałobny uwypukla męki cielesne, odchodząc wyraźnie od poetyki dramatu tragicznego, który skupia się na działaniach bohaterów, a nie na ich cierpieniach. Na scenie teatru wewnętrzne opanowanie, samokontrola i wytrwałość męczennika przedstawiane są na drodze okrężnej poprzez ostentacyjne demonstrowanie fizycznych symptomów bólu. W konsekwencji duchowa gloria zostaje tutaj przemieszczona na dalszy plan, dając pierwszeństwo niemal ekshibicjonistycznemu spektaklowi kaźni. Zwycięstwo wytrwałej duszy ukazywane jest i zaświadczane za pośrednictwem ostentacyjnej, przesadnej ekspresji, lamentów, zawodzeń, spazmów torturowanego męczennika. W dramacie żałobnym nie poświęca się wiele miejsca na ukazywanie przyczyn męczeństwa tortury są najczęściej efektem despotycznej decyzji tyrana. Męczennicy cierpią z powodu swojej nieustępliwej wiary, jak królowa Catharnia, która odmawia przejścia na islam (w sztuce Andreasa Gryphiusa Catharina von Georgien). Dla Benjamina istotne w postaci męczennika, jest to, że funkcjonuje on jako osoba, która dogłębnie doświadcza żałości, ale nie popada $\mathrm{w}$ wewnętrzną pustkę. Jego fizyczne katusze nie są jedynie bezsensownymi (czysto fizjologicznymi) reakcjami na ból, lecz niosą ze sobą znaczenie, co wyraźnie odróżnia go od Freudowskiego melancholika, u którego fizyczne symptomy potwierdzają tylko wewnętrzny roz- 
pad. Ciało męczennika znajduje się na progu życia i śmierci, a zatem ani nie należy w pełni do domeny życia, ani nie jest całkiem obumarłe, lecz ujawnia swoją czystą materialność, stając się alegorycznym emblematem upadłego świata rzeczy, w którym tkwi jeszcze iskra mesjańskiej nadziei na zbawienie. Udręczone ciało daje również świadectwo wspólnej martyrologii zanurzonego w katastroficznym biegu historii człowieka i upadłej natury. Męczeństwo odpowiada strukturalnie pracy alegoryka, który wydobywa znaczenie $\mathrm{z}$ fragmentów materialnego świata.

To samo sedno patrzenia alegorycznego, barokowej, świeckiej ekspozycji historii jako męczeńskich dziejów świata; znaczenie mają tylko kolejne stacje jej upadku. Tyle znaczenia, ile śmiertelności, ponieważ to śmierć najgłębiej wyrzyna zębatą linię demarkacyjną między fizycznością a znaczeniem. Jeśli jednak natura od zawsze jest śmiertelna, to od zawsze też alegoryczna. Znaczenie i śmierć tak jak są wytworami rozwoju historycznego, tak też przenikają się nawzajem jako zarodki w nieobjętym łaską stanie grzeszności stworzenia ${ }^{29}$.

Benjamin stawia znak równości pomiędzy rozczłonkowanym ciałem męczennika a rozproszoną materią którą poddaje swobodnej interpretacji barokowy alegorysta. Cielesność nabiera tutaj poniekąd semiotycznego charakteru, jej spazmy odpowiadaja konwulsjom barokowego języka, który eksperymentuje ze słowami, lubuje się w neologizmach, onomatopejach, kunsztownych, przestylizowanych formach, anagramach, hieroglifach. Jak pisze Benjamin:

Językiem baroku niezmiennie wstrząsają rebelie jego elementów [...] Słowa choć odosobnione, okazują się pełne fatalnej treści [...] W ten sposób kruszy się język, aby w swoich ułamkach uzyskać odmienny, silniejszy wyraz ${ }^{30}$.

W oczach barokowego alegoryka świat rzeczy jawi się jako rumowisko rozbitego na fragmenty świata. Takiej wizji odpowiada używany przez niego zdysocjowany język, w którym istotną rolę odgrywają poszczególne słowa-emblematy, a niekiedy pojedyncze misternie ukształtowane litery. Działa tutaj zasada symbolicznej destrukcji (obrazu świata i samego języka, który traci funkcje komunikacyjne). Alegorysta symbolicznie niszczy świat, aby wyłuskać z niego znaczenie ukryte pod fasadą konwencjonalnej semantyki. Warunkiem odsłonięcia ukrytego sensu jest symboliczna śmierć (mowy i świata) doświadczana przez alegorystę i uwidoczniona dosłownie $\mathrm{w}$ agonii męczennika.

29 Ibidem, s. 217-218.

30 Ibidem, s. 278-279. 
Jeśli potem w chwili śmierci duch staje się wolny, sposobem właściwym dla duchów, to również ciało dopiero dostępuje swojego najwyższego prawa. Albowiem rozumie się samo przez się: energiczna alegoryzacja fizyczności nie może się ziścić bez zwłok. Bohaterowie dramatu żałobnego umierają więc, gdyż jedynie w ten sposób - jako zwłoki - mogą się zadomowić w alegorii. Giną nie gwoli nieśmiertelności, lecz po to, by stać się zwłokami ${ }^{31}$.

Zwrot "ciało dostępuje swojego najwyższego prawa" wskazuje, że wraz z śmiercią staje się ono czytelne dla alegorycznego spojrzenia i uzyskuje dlań głębsze znaczenie. Dlatego też, jak podkreśla Benjamin, zwłoki, a nie nieśmiertelna dusza bohatera (jak w tragedii), stają się $\mathrm{w}$ dramacie żałobnym najważniejszym rekwizytem emblematycznym.

Nadmierny, letalny ból męczennika rozrywa granicę między życiem a śmiercią. Ten pośredni stan przywodzi na myśl uwagę Freuda, że w melancholii utracony obiekt nie jeszcze czymś martwym, ale właściwie już nie żyje (jako coś realnego). Dla twórcy psychoanalizy zatarcie granicy między istnieniem i nieistnieniem utraconego obiektu charakterystyczne dla melancholijnego doświadczenia powoduje, że należy je uznać za stan patologiczny, który uniemożliwia melancholikowi przystąpienie do pozytywnej pracy żałoby. Zamiast pogodzić się z utrata, melancholik bezwiednie żłobi w swoim wnętrzu grobowiec dla utraconego obiektu, zmienia tym samym swoją wewnętrzną topografię, w której ego zaczyna koegzystować z widmową i obcą częścią samego siebie. Nieuświadomiony Doppelgänger Ja zaczyna je nawiedzać i nękać niczym złowrogi duch. Analogia między koncepcją melancholii Freuda a motywem męczeństwa w interpretacji Benjamina kończy się jednak w tym punkcie, ponieważ $\mathrm{w}$ przypadku męczennika nie dochodzi do rozdwojenia w obrębie ego. Jego dusza zachowuje stoicką stałość i niezłomność w wierze, wyczekuje ratunku, ocalenia, które przychodzi z zewnątrz w postaci łaski Bożej. Okaleczone, widmowe ciało rozpada się, a dusza przechodzi w stan transcendencji. Działa tutaj zatem jeszcze średniowieczny schemat eschatologiczny, choć uwikłany w katastroficzną wizję świata barokowego dramatu, w której życie okazuje się ostatecznie - jak powiada Benjamin - nieustanną produkcją zwłok, odraczanym w nieskończoność rozpadem. Opuszczone przez duszę, pokryte inskrypcjami ran i blizn ciało męczennika, które zamienia się w zwłoki, nie stanowi więc symbolu zbliżającego się zbawienia, jak chciało średniowiecze, lecz przede wszystkim alegorię życia stopionego bez reszty z śmiercią. Jego widmowy charakter dałoby się co najwyżej zestawić z pierwszym stadium Freudowskiej melancholii i żałoby, w którym podmiot porzuca świat i poddaje się rozmaitym praktykom samoudręczania. W męczeń-

31 Ibidem, s. 294. 
skiej reakcji na żałość nie widać jednak jakiejkolwiek możliwości powrotu do świata (jak w żałobie), a jedynie pełne stopienie się $\mathrm{z}$ utraconym obiektem (tutaj z Imago Dei), które z perspektywy nieteologicznej oznacza śmierć duszy. Brakuje tutaj, jak już wspomniano, typowego dla melancholii rozdwojenia ego.

\section{Nieudana śmierć - postać ducha-zjawy}

Motyw widma, fantomu duszy zamieszkującego migotliwy obszar między życiem a śmiercią który nawiedza podmiot, przedstawia sobą jednak inna figura charakterystyczna dla barokowego dramatu żałobnego, a mianowicie postać ducha. Duchy pojawiają się w większości utworów tego gatunku jako zjawy zmarłych lub widma żyjących ludzi, uosabiają wizję śmierci jako przypadkowego, niekończącego się procesu. Ten osobliwy status śmierci jako nieustającego ruchu między agonią a życiem stanowi istotny rys Trauerspiel. Benjamin porównuje go w innym tekście z wyobrażeniem śmierci charakterystycznym dla greckiej tragedii:

W tragedii bohater umiera, ponieważ nikt nie może żyć w czasie spełnionym. Umiera na nieśmiertelność. Śmierć jest ironiczną nieśmiertelnością [...] ironiczną z powodu nadmiernej determinacji [...] Śmierć $\mathrm{w}$ dramacie żałobnym nie polega na owym absolutnym zdeterminowaniu, które nadaje zdarzeniu piętno indywidualnego czasu. [...] Pod względem matematycznym dramat żałobny przypomina ramię hiperboli, której drugie ramię leży w nieskończoności. Prawo rządzące wyższym życiem obowiązuje $\mathrm{w}$ ograniczonej przestrzeni ludzkiego istnienia i wszyscy grają tu, dopóki śmierć nie zakończy gry, po to, aby powtarzać tę samą grę tyle, że w większej skali, w innym świecie. Prawo rządzące dramatem żałobnym opiera się na powtórzeniu. Jego zdarzenia są alegorycznymi schematami, symbolicznymi lustrzanymi odbiciami innej gry. Do tej gry przenosi śmierć3

Śmierć tragiczna to śmierć będąca skutkiem opatrznościowej determinacji, jest ona rodzajem ostatecznego finału, śmierć dramatu żałobnego nie ustaje, nie kończy się. Jej repetytywny charakter opisuje Benjamin za pomocą metafory hiperboli, czyniąc aluzję do nieskończonego "ruchu" zbliżania się ramion tej figury do jej asymptot. Greckie słowo hyperbole oznacza dosłownie stan nadmiaru, co doskonale opisuje Benjaminowskie rozumienie statusu śmierci w Trauerspiel. Jak hiperbola śmierć nigdy nie zatrzymuje się, nie dociera do końca, jest nadmiarowa, nieustannie powtarza się. W dramacie żałobnym brakuje doniosłości,

32 W. Benjamin, Trauerspiel und Tragödie, w: idem, Gesammelte Schriften II.1, Frankfurt am Main 1991, s. 135-136. 
konkluzywności śmierci, brakuje jakichkolwiek ostatecznych rozwiązań. Śmierć ukazana jest jako niekończąca się gra zwierciadlanych odbić, która nie dobiega kresu. Przejście do wyższego wymiaru życia zostaje tutaj szczelnie zamknięte, dlatego „zmarli stają się zjawami”"33. Los tragicznego bohatera jest indywidualny. Traci on swoje życie, ale zyskuje „nieśmiertelność” imienia, które w glorii sławy wkracza do zbiorowej pamięci potomności i symbolicznie konsoliduje wspólnotę. Natomiast bohater dramatu żałobnego, ,,[...] umierając, traci imienną indywidualność, ale nie siłę witalną swojej woli"34. Duchy zmarłych są zatem przejawem witalności oderwanej od strumienia życia biologicznego. Zjawy, jak podkreśla Benjamin, „to zjawiska z królestwa żałości”, stanowią zatem niejako zewnętrzny ekwiwalent zinterioryzowanego przez melancholika utraconego obiektu, który już nie żyje, ale nie może jeszcze przekroczyć progu śmierci. Duchy ukazują się tylko wybranym osobom, dają im możliwość sprawowania kontroli nad własnym losem, stąd śmierć w dramacie żałobnym nie ma charakteru nieodwracalnej konieczności. Fatum rozprasza się na zmultiplikowane pojedyncze, pozbawione nieuchronności „losy”, którymi można manipulować za pośrednictwem duchów. Dlatego dramat żałobny wychodzi poza schemat Freudowskiej melancholii, w który wpisuje się raczej tragedia. Tragiczne fatum daje się bowiem zinterpretować jako zewnętrzny przejaw numinotycznej, ślepej i nie poddającej się negocjacjom siły uwewnętrznionego przez melancholika i niszczącego go obiektu. Melancholia dramatu żałobnego nie zna tego rodzaju konieczności czy absolutnej determinacji. Widmowy „utracony obiekt" charakteryzuje przypadkowość, ponieważ o tym, czy może się on ukazać ludziom, decyduje kontyngentny, niezdeterminowany układ okoliczności. Niekiedy, jak w sztuce Sophia Hallmanna, na scenie przed bohaterką pojawiają dwa wizerunki śmierci - dwa trupy ze strzałami, które alegorycznie wyrażają dwa przypuszczalne warianty końca życia główniej bohaterki, a właściwie niemożność dostąpienia przez nią pojedynczej, ostatecznej śmierci. Zjawa nie reprezentuje pojednania życia i śmierci, zapowiada jedynie transformację biegu scenicznych zdarzeń lub zmianę życia głównego bohatera. Ta zapowiedź jest zawsze złowróżbna.

Duchy egzystuja zdaniem Benjamina, w osobliwym ahistorycznym wymiarze, w którym trzy wymiary czasu tworzą symultaniczna, niemal przestrzenną konstelację. Dlatego też nawiedzają protagonistów, ukazując znaki będące przesłaniem płynącym zarówno z przeszłości, jak i z przyszłości, przy czym w owej pozaczasowej przestrzeni widmowości nie obowiązują prawa determinizmu, tylko gra zwierciadlanych odbić nie odsyłających do ostatecznego celu, rozstrzygnięcia czy znaczenia.

33 W. Benjamin, Źródło dramatu żałobnego..., op. cit., s. 136.

34 Ibidem, s. 171. 
Możemy dostrzec tu pewną analogię do Freudowskiej tezy, że procesy zachodzące w nieświadomości są atemporalne, ponieważ żadna instancja nie porządkuje ich według jakiejś określonej chronologii. Wyparte obrazy obsadzone energią libidalną trwają poniekąd w stanie niezmienionym, dążąc podskórnie do aktualizacji w sprzyjających okolicznościach. Duch-zjawa jako wyparty z świadomości obiekt, będący jednak nieświadomą częścią ego, komunikuje się z duszą bohatera, przybierając formę wizualnej i akustycznej halucynacji, jak powiedziałby Freud. Przy czym najważniejsza jest akustyczna forma przejawiania się widma. Dostrzec je mogą wprawdzie również osoby postronne jak Horatio i strażnicy w Hamlecie Szekspira, jednakże usłyszeć przekaz może tylko i wyłącznie osoba, do której widmowy głos jest ostatecznie adresowany. Aby móc usłyszeć pełne przesłanie ducha, należy spełnić dwa warunki. Po pierwsze, wymagane jest odpowiednie nastawienie wobec przeszłości, to znaczy, pełna akceptacja jej roszczeń, a po drugie, głos domaga się zawsze odpowiedzi na swoje przesłanie. Na spełnianiu obydwu warunków polega wspomniany wcześniej etyczny wymiar żałości. Nie chodzi w niej bowiem o zapomnienie, o wyparcie traumatycznej straty i powrót do świata, lecz o podjęcie wyzwania, które ona w sobie kryje. Ukazujące się świadomości obrazy (halucynacyjne widma) niosą ze sobą groźbę, że znikna, jeśli tylko jeden ze wspomnianych wyżej warunków nie zostanie spełniony. W perspektywie psychoanalitycznej zniknięcie widma oznaczałoby utratę dostępu do "czasu utraconego", do ważnych dla życia psychicznego śladów własnej prehistorii, które z ukrycia dręczą świadomość, zamykają ją na nowe doświadczenia i wpędzają w stan wewnętrznego rozpadu. Widmo jako słyszalne echo nieurzeczywistnionych roszczeń wypartej przeszłości wyraża pragnienie pełnej śmierci, która może nastąić tylko wtedy, gdy jego zalecenia zostaną urzeczywistnione w teraźniejszości.

Postać ducha stanowi jeden z elementów charakteryzujących barokową żałość. Jak pamiętamy, w melancholijnym uniwersum baroku z utraconym i nieuświadomionym "obiektem" zmagają się nie tylko poszczególne jednostki, wspólnota, ale również jej język i sama natura rzeczy. Wszystko przenika żałość będąca stanem świata całkowicie odciętego od transcendencji i chylącego się ku upadkowi. Duch jako widmowy ślad po „nieumarłej” przeszłości nie jest ostatecznie w stanie przekroczyć progu prowadzącego do wyższego świata, ale przekazuje etyczne przesłanie, którego realizacja daje nadzieję na przerwanie kontinuum dziejowej katastrofy. Realizacja tego przesłania niezależnie od tego, na czym miałaby ona polegać, oznaczałaby ostateczne uśmiercenie widmowego obiektu równoznaczne z jego wybawieniem. Benjamin nie dostrzega możliwości takiego finału w epizodach z duchami zmarłych, które pozostają nieodwołalnie zamknięte w sferze immanencji. Wyzwalający, mesjański moment rozpoznaje natomiast $\mathrm{w}$ alegoryczności języka 
dramatu żałobnego. To stanowi o osobliwości jego interpretacji. Iskrę nadziei w upadającym świecie da się bowiem odnaleźć, jego zdaniem, jedynie w alegoryzującym świat języku melancholika-filozofa. Uchwycenie właściwego sensu barokowej melancholii wymaga zatem analizy koncepcji alegoryczności, którą przedstawię w drugiej części tego artykułu.

\section{Bibliografia}

Benjamin W., Źródło dramatu żałobnego w Niemczech, przeł. A. Kopacki, Warszawa 2013.

Benjamin W., O języku w ogóle i o języku człowieka, w: idem, Konstelacje. Wybór tekstów, przeł. A. Lipszyc, A. Wołkowicz, Kraków 2012.

Benjamin W., Trauerspiel und Tragödie, w: idem, Gesammelte Schriften II.1, Frankfurt am Main 1991.

Blumenberg H., Legitimität der Neuzeit, Frankfurt am Main 1988.

Buci-Glucksamann Ch., Baroque Reason. The Aesthetics of Modernity, London 1994.

Freud S., Żałoba i melancholia, w: idem, Psychologia nieświadomości, przeł. R. Reszke, Warszawa 2009.

Freud S., Ja i to, w: idem, Psychologia nieświadomości, przeł. R. Reszke, Warszawa 2009, s. 149.

Klibansky R., Panofsky E., Saxl F., Saturn i melancholia, Studia z historii, filozofii, przyrody i medycyny, religii oraz sztuki, przeł. A. Kryczyńska, Kraków, 2009.

Michalski R., Antropologia mimesis. Studium myśli Waltera Benjamina i Theodora W. Adorna, Wyd. Rolewski 2008.

Radden J., The nature of melancholy. From Aristotle to Kristeva, Oxford 2000.

Schmitt C., Teologia polityczna, w: idem, Teologia polityczna $i$ inne pisma, przeł. M. A. Cichocki, Warszawa 2012.

Scholem G., The Messianic Idea in Judaism and Other Essays in Jewish Spirituality, New York 1971.

Stewart E., Catastrophe and Survival. Walter Benjamin and Psychoanalysis, New York 2010. 


\section{Streszczenie}

Przedmiotem dociekań zawartych w artykule jest koncepcja melancholii Waltera Benjamina przedstawiona w jego rozprawie Źródło dramatu żałobnego w Niemczech. Rekonstrukcja głównych tez tej koncepcji zostanie dokonana na tle psychoanalizy. Według Benjamina melancholia przenika całe uniwersum barokowego dramatu, sygnalizując rozpad panującego porządku. Jako symptom głębokiego zwątpienia w sens świata może ona prowadzić do katastrofy, ale również otwierać przestrzeń prawdy i nadziei. Ta ambiwalencja, a właściwie dialektyka upadku i ocalenia będzie głównym przedmiotem analiz artykułu. W pierwszej części przedstawię bardziej szczegółowo Benjaminowskie ujęcie żałości w kontekście psychoanalizy (1), następnie omówię główne formy reakcji na melancholijne doświadczenie utraty ukazane paradygmatycznie w postaciach: tyrana (2), męczennika (3) i ducha-zjawy (4).

Słowa kluczowe: Walter Benjamin, historia, dramat żałobny, melancholia, władza suwerenna, męczeństwo, alegoria

\section{Summary}

\section{Melancholy and Catastrophe in a Baroque Mourning Drama}

The subject of the investigations contained in the article is the concept of melancholy by Walter Benjamin presented in his dissertation The Origin of German Tragic Drama. The reconstruction of the main theses of this concept will be made against the background of psychoanalysis. According to Benjamin, melancholy permeates the entire universe of the baroque drama, signaling the disintegration of the prevailing order. As a symptom of a deep doubt in the sense of the world, it can lead to a catastrophe but also open the space of truth and hope. This ambivalence, or rather the dialectics of the fall and the salvation, will be the main subject of the analysis in the article. In the first part, I will present in more detail Benjamin's approach to melancholy in the context of psychoanalysis (1); then, I will discuss the main forms of reaction to the melancholic experience of the loss paradigmatically shown in the forms of the tyrant (2), the martyr (3), and ghost-phantom (4).

Keywords: Walter Benjamin, history, mourning drama, melancholy, sovereign power, martyrdom, allegory 